\title{
THE EFFECT OF PHYSICAL PRIMING OF SEED ON TRAITS AND YIELD OF CORN (ZEA MAYS L.) UNDER WATER DEFICIT CONDITIONS IN IRAN
}

\author{
SIYAMI, R. ${ }^{1}-$ MirShEKARI, B. ${ }^{1 *}-$ FARAHVASH, F. $^{1}-$ RASHIDI, V. ${ }^{1}-$ TARINEJAD, A. ${ }^{2}$ \\ ${ }^{I}$ Department of Agronomy and Plant Breeding, Tabriz Branch, Islamic Azad University \\ Tabriz, Iran \\ ${ }^{2}$ Department of Agricultural Biotechnology, Faculty of Agriculture, Azarbaijan Shahid Madani \\ University, Tabriz, Iran \\ *Corresponding author \\ e-mail: mirshekari@iaut.ac.ir \\ (Received $7^{\text {th }}$ Aug 2017; accepted $18^{\text {th }}$ Dec 2017)
}

\begin{abstract}
In order to study the effect of physical priming of seed on traits and yield of corn under water deficit conditions, a two years experiment was conducted during 2014- 2015 as a split plot with three replications in Iran. The main factor includes two levels of irrigation (70 and $110 \mathrm{~mm}$ evaporation from pan class A as control and water deficit, respectively) after 8-9 leaves stage of corn and sub-factor includes corn seed treatment with gamma and beta rays, laser wave, magnetic field and ultrasonic waves, all in time intervals of 5 and $10 \mathrm{~min}$. along with a non-primed control. Results indicated that maize seed priming under magnetic field of 5 and $10 \mathrm{~min}$. and gamma and laser rays for $5 \mathrm{~min}$. in normal irrigation regime were the best treatments with $20 \%, 18 \%, 16 \%$ and $13 \%$ increase value, respectively, while seed priming with gamma and laser rays for $10 \mathrm{~min}$. under water deficit condition had the lowest grain yield. To increase corn grain yield in both normal and water deficit conditions, seed priming with the magnetic field in both time intervals, gamma and laser rays only in a short time is recommended.
\end{abstract}

Keywords: evaporation, gamma ray, grain, laser wave, magnetic field

\section{Introduction}

Maize (Zea mays L.) is one of the most important cereal crops in the world therefore its cultivation is economically important and also due to its agricultural importance many fundamental researches have been conducted in a century on this plant (Marcu et al., 2013). According to Khan et al. (2008) seed priming is a pre-sowing strategy to improve germination and seedling establishment through priority of metabolic activities before emergence of radicle that often leads to more moisture, nutrients, and sunlight absorption and ultimately lead to increased yield.

According to Aladjadjiyan (2014), use of some physical elements are considered as a modern method for achieving higher yields in agricultural systems. Interest for use of ecological factors influencing plant products such as laser radiation, ultra violet, magnetic and electric fields has been increased (Faqenabi et al., 2009). Paolo and Rinaldi (2008) stated that the adverse effects of water stress on growth and development and yield of corn depends on the time of stress, stress tension, plant developmental stage, and its genotype. In a research study, the lowest grain yield of corn was obtained from those plants that under water deficit in flowering stage (Rabbani and Imam, 2011). Despite existence of limited information on physical methods of seed treatment, interest and willingness to use of these methods for seed priming crop plants has increased in recent years (Hernández et al., 2010). 
Gamma ray is the most important physical treatment that increases production in crop plants such as rice (Oryza sativa), corn, bean (Phaseolus vulgaris), and potato (Solanum tuberosum) (Mokobia and Anomohanran, 2005). Potato tubers pre-treated with gamma ray before sowing improved plant growth characteristics (Hamideldin and Hussin, 2014). Increase in the height and fresh weight of corn and followed by increase in the performance has been reported by seed treatment with magnetic fields (Racuciu et al., 2008). In an experiment conducted by Pietruszewski and Kania (2010) use of some physical treatments including magnetic field and laser radiation before sowing the seed increased grain yield of wheat. Exposure of sunflower (Helianthus annuus) seeds to magnetic fields gave rise to positive effects on plant growth and increased yield (Vashisth and Nagarajan, 2013). Rochalska (2008) reported that sugar beet (Beta vulgaris) seed priming with magnetic field leads to more rapid plant growth, due to the intensity of metabolic processes, and finally yield improvement.

Since the physical priming is one of the effective methods in improving the crop yield in preserving the natural environment and biological safety, then the specific aims of this study were:

- Evaluation effect of the studied treatments on morpho-physiological traits of corn

- Response of biomass and grain yields of corn crop to biophysical studied treatments

\section{Materials and Methods}

Maize is a tall, monecious annual plant of Poaceae family. It has staminate spikelets in long spike-like racemes that form large spreading terminal tassels and pistillate inflorescences in the leaf axils (Anonymous, 2015).

\section{Site description}

This research was carried out in two years (2014- 2015) at the Agricultural Research Station of Islamic Azad University, Tabriz Branch, Iran. The regional climate is semiarid and cold. The location of this experiment was $1560 \mathrm{~m}$ above sea level by $38^{\circ} 5^{\prime} \mathrm{N}$ and $46^{\circ} 17^{\prime}$ E geographical latitude and longitude, respectively.

\section{Experimental design and variables}

The experiments were carried out as split plot based on the randomized complete blocks design with three replications on the corn SC260. The main factor includes irrigation time ( $70 \mathrm{~mm}$ as normal treatment, and $110 \mathrm{~mm}$ evaporation from pan class $\mathrm{A}$ as water deficit treatment after 8-9 leaves stage of corn) and sub-factor was in 11 levels of seed treatment with gamma (cobalt 60) (Farahvash et al., 2007) and beta rays (strontium 90) (Bradford, 1995), both with constant intensity of two microcurie, continuous wave helium-neon laser with a wavelength of 6328 angstroms (Chen et al., 2002), magnetic field of $40 \mathrm{mT}$ (Iqbal et al., 2012), and ultrasonic waves with a maximum of three $\mathrm{Wcm}^{-1}$ (Yaldagard and Mortazavi, 2008) all in 5 and $10 \mathrm{~min}$. intervals along with control. 


\section{Equipment's used and seed treatment}

Before applying the treatments, corn seeds were put in hypochlorite sodium 5\% for two minutes for disinfection and then were washed three times with distilled water. The seeds were kept in dark place for $24 \mathrm{~h}$ in distilled water at a temperature of $25^{\circ} \mathrm{C}$ (Artola et al., 2003) and then physical treatments were applied on the seeds inside petri dishes in Physics Laboratory. In order to pre-treatment of seeds with gamma and beta rays, laser wave, magnetic field, and ultrasonic wave were used lead syringe source of LEYBOLD (Germany), laser device IR2000 (Iran), transformer 2086 (Iran) and ultrasonic device of Sa-Iran company, respectively.

\section{Land preparation}

The experimental area was ploughed in the fall and then disked in early spring. After preparing the experimental plots, treated seeds were sown immediately in the field. Sowing was conducted every two years on May 10 at a distance of $75 \mathrm{~cm}$ between the rows on the rows of $20 \mathrm{~cm}$ at density of $67000 \mathrm{P} \mathrm{ha}^{-1}$ and a depth of $3-4 \mathrm{~cm}$. Based on the results of soil analysis, ammonium phosphate and potassium sulfate fertilizers were used as 110 and $100 \mathrm{~kg} \mathrm{ha}^{-1}$, respectively before sowing and nitrogenous fertilizer was added as $80 \mathrm{~kg} \mathrm{ha}^{-1}$ from urea source in two equal parts at each stage of sowing and on the corn stem elongation (4-5 leaves stage) as strips to the soil. Weeds control was carried out manually as needed two times during the growing season. Irrigation was conducted from the time of sowing the seeds until the beginning of water deficit treatment equally in all treatments based on $70 \mathrm{~mm}$ evaporation from pan and then continued to the end of the growing season depending on the type of treatment based on the 70 and $110 \mathrm{~mm}$ of evaporation.

\section{Studied traits}

At the time of ripening, plant height, time of tasseling, leaf area index (LAI), stem dry weight, leaf proline concentration, biomass and grain yield were measured based on standard procedures. Also, LAI was measured by the method of described by Acquaah (2002). Leaf proline concentration was determined using a spectrophotometer at a wavelength of $520 \mathrm{~nm}$ (Bates et al., 1973).

\section{Statistical analysis}

Variance analysis of data was achieved using MSTAT-C software (Alizadeh and Tarinejad, 2010) and Duncan Multiple Range Test at 5\% was used for mean comparisons. Excel software was used to drawing the figures.

\section{Results}

Combined variance analysis on the effects of irrigation levels and physical seed treatments on the studied traits in corn revealed that the year effect on all traits, the effect of irrigation level on stem dry weight and grain yield, interaction of year and irrigation level on the plant height and leaf proline concentration, the effect of physical pre-treatment on all traits, interaction of irrigation level in physical pre-treatment on the biomass and grain yield per unit area was significance at $\mathrm{p}<0.05$ (Table 1$)$. 
Table 1. Combined variance analysis of irrigation levels and seed physical pre-treatments on studied traits of corn in two years of experiment.

\begin{tabular}{|c|c|c|c|c|c|c|c|c|}
\hline (S.O.V) & $\begin{array}{l}\text { Degree of } \\
\text { freedom } \\
\text { (df) }\end{array}$ & Plant height & $\begin{array}{l}\text { Time of } \\
\text { tasseling }\end{array}$ & LAI & $\begin{array}{l}\text { Stem dry } \\
\text { weight }\end{array}$ & $\begin{array}{l}\text { Leaf proline } \\
\text { concentration }\end{array}$ & $\begin{array}{c}\text { Biomass per } \\
\text { unit area }\end{array}$ & Grain yield \\
\hline $\mathrm{Y}$ & 1 & $15356.54 * *$ & $1749.09 * *$ & $1.94 *$ & $8754.73 * *$ & $33.83^{*}$ & $1368843.66^{* *}$ & $191496.71 * *$ \\
\hline $\mathrm{R} / \mathrm{Y}$ & 4 & 139.93 & 80.01 & 0.19 & 119.93 & 2.85 & 13289.17 & 2750.50 \\
\hline $\mathrm{A}$ & 1 & $6119.33^{\text {ns }}$ & $643.72^{\mathrm{ns}}$ & $17.03^{\mathrm{ns}}$ & $7500.18^{*}$ & $54.49^{\mathrm{ns}}$ & $1191680.03^{\mathrm{ns}}$ & 517338.92* \\
\hline$A \times Y$ & 1 & $264.20 *$ & $4.18^{\mathrm{ns}}$ & $0.63^{\mathrm{ns}}$ & $9.28^{\mathrm{ns}}$ & $4.22 * *$ & $10945.48^{\mathrm{ns}}$ & $279.27^{\mathrm{ns}}$ \\
\hline $\mathrm{A} / \mathrm{Y} \times \mathrm{R}$ & 4 & 14.61 & 38.62 & 0.13 & 2.60 & 0.04 & 6795.96 & 5733.10 \\
\hline B & 10 & $4107.17 * *$ & $424.19 * *$ & $4.16^{* *}$ & $1969.54 * *$ & $5.39 * *$ & $162520.51 * *$ & $64373.34 * *$ \\
\hline $\mathrm{B} \times \mathrm{A}$ & 10 & $51.35^{\text {ns }}$ & $5.96^{\mathrm{ns}}$ & $0.03^{\mathrm{ns}}$ & $55^{\mathrm{ns}}$ & $0.76^{\mathrm{ns}}$ & $3505.61 *$ & $422.40^{*}$ \\
\hline $\mathrm{B} \times \mathrm{Y}$ & 10 & $112.29^{\mathrm{ns}}$ & $16.12^{\mathrm{ns}}$ & $0.09^{\mathrm{ns}}$ & $28.82^{\mathrm{ns}}$ & $0.46^{\mathrm{ns}}$ & $2167.48^{\mathrm{ns}}$ & $539.69^{\mathrm{ns}}$ \\
\hline $\mathrm{B} \times \mathrm{A} \times \mathrm{Y}$ & 10 & $31.40^{\mathrm{ns}}$ & $2.76^{\mathrm{ns}}$ & $0.04^{\mathrm{ns}}$ & $30.76^{\mathrm{ns}}$ & $0.43^{\mathrm{ns}}$ & $1146.40^{\mathrm{ns}}$ & $140.32^{\mathrm{ns}}$ \\
\hline $\mathrm{B} / \mathrm{YA} \times \mathrm{R}$ & 80 & 164.45 & 29.86 & 0.13 & 79.15 & 0.95 & 14430.58 & 5296.97 \\
\hline C.V. (\%) & - & 6.03 & 7.80 & 10.69 & 12.01 & 21.26 & 9.50 & 11.26 \\
\hline
\end{tabular}

$\mathrm{ns}, *$, and $* *$ are non-significant, significant at $5 \%$ and $1 \%$ probability levels, respectively.

$\mathrm{Y}, \mathrm{R}, \mathrm{A}$, and B mean year, replication, irrigation levels and physical pre-treatments, respectively. 


\section{Plant height}

Based on the comparing the means, seed treatment with magnetic fields for 5 and 10 min. and laser radiations and gamma for $5 \mathrm{~min}$. had the highest plant height while the lowest value from 10 min. treatment with gamma radiation (Table 2).

Table 2. Mean comparisons of seed physical pre-treatments on studied traits of corn in two years.

\begin{tabular}{c|c|c|c|c|c}
\hline $\begin{array}{c}\text { Seed pre- } \\
\text { treatment }\end{array}$ & $\begin{array}{c}\text { Plant } \\
\text { height }(\mathbf{c m})\end{array}$ & $\begin{array}{c}\text { Time of } \\
\text { tasseling } \\
(\mathbf{d a y})\end{array}$ & LAI & $\begin{array}{c}\text { Stem dry } \\
\text { weight }(\mathbf{g})\end{array}$ & $\begin{array}{c}\text { Leaf proline } \\
\text { concentration } \\
(\boldsymbol{\mu m o l} / \mathbf{g})\end{array}$ \\
\hline Control & $202.68 \mathrm{~cd}$ & $69.70 \mathrm{bc}$ & $3.16 \mathrm{~d}$ & $66.66 \mathrm{e}$ & $4.30 \mathrm{~cd}$ \\
Gamma 5 min. & $227.45 \mathrm{~b}$ & $66.43 \mathrm{~cd}$ & $3.85 \mathrm{~b}$ & $84.27 \mathrm{~b}$ & $5.73 \mathrm{a}$ \\
Gamma 10 min. & $180.64 \mathrm{e}$ & $80.06 \mathrm{a}$ & $2.37 \mathrm{e}$ & $51.97 \mathrm{f}$ & $3.85 \mathrm{de}$ \\
Beta 5 min. & $204.18 \mathrm{c}$ & $71.58 \mathrm{~b}$ & $3.38 \mathrm{~cd}$ & $72.50 \mathrm{~cd}$ & $4.31 \mathrm{~cd}$ \\
Beta 10 min. & $209.97 \mathrm{c}$ & $70.22 \mathrm{bc}$ & $3.52 \mathrm{c}$ & $76.25 \mathrm{c}$ & $4.98 \mathrm{bc}$ \\
Laser 5 min. & $229.66 \mathrm{ab}$ & $63.56 \mathrm{de}$ & $4 \mathrm{ab}$ & $82.50 \mathrm{~b}$ & $4.98 \mathrm{bc}$ \\
Laser 10 min. & $193.35 \mathrm{~d}$ & $78.52 \mathrm{a}$ & $2.59 \mathrm{e}$ & $56.45 \mathrm{f}$ & $3.48 \mathrm{e}$ \\
Magnetic 5 min. & $238.87 \mathrm{a}$ & $62.25 \mathrm{e}$ & $4.16 \mathrm{a}$ & $91.77 \mathrm{a}$ & $4.94 \mathrm{bc}$ \\
Magnetic 5 min. & $236.18 \mathrm{ab}$ & $62.77 \mathrm{de}$ & $4.10 \mathrm{ab}$ & $90.52 \mathrm{a}$ & $5.32 \mathrm{ab}$ \\
Ultrasonic 5 min. & $202.81 \mathrm{~cd}$ & $72.14 \mathrm{~b}$ & $3.18 \mathrm{~d}$ & $70.10 \mathrm{de}$ & $4.50 \mathrm{~cd}$ \\
Ultrasonic 10 min. & $211.70 \mathrm{c}$ & $72.43 \mathrm{~b}$ & $3.36 \mathrm{~cd}$ & $71.56 \mathrm{cde}$ & $4.04 \mathrm{de}$ \\
\hline LSD \%5 & 9.64 & 3.652 & 0.280 & 4.884 & 0.622 \\
\hline
\end{tabular}

Means in each column with similar letters have not significant difference based on DMRT at $5 \%$ probability level.

\section{Time of tasseling}

Minimum tasseling time obtained from those seeds treated with magnetic fields for 5 and $10 \mathrm{~min}$., laser radiations and gamma for $5 \mathrm{~min}$., while the maximum time to tasseling was measured in gamma and laser rays for $10 \mathrm{~min}$., so that the use of them leads to happening 6 days earlier and 10 days delay in the adventure of tasseling, respectively compared to the control (Table 2$)$.

\section{LAI}

LAI increased by corn seed priming with magnetic field in both time intervals and laser and gamma rays for $5 \mathrm{~min}$., as $22.27 \%$, and $32 \%$, respectively compared to the control. Extending of duration of seed priming with both gamma and laser rays from 5 to $10 \mathrm{~min}$. led to reduction of corn leaf area compared to the control as $25 \%$ and $18 \%$, respectively (Table 2).

\section{Stem dry weight}

Stem dry weight of corn decreased by $15 \%$ due to water deficit compared to the normal irrigation (Figure 1). The highest dry weight obtained from those seeds under magnetic field treatments of 5 and $10 \mathrm{~min}$. followed by gamma and laser rays for $5 \mathrm{~min}$. The reducing effect of gamma and laser for $10 \mathrm{~min}$. on dry weight was significant. So that, seed treatment with the above radiations led to $22 \%$ and $16 \%$ reduction on dry 
weight. Seed treatment with beta radiation in both time intervals revealed better efficacy compared with ultrasonic wave and $9.59 \mathrm{~g}$ and $5.84 \mathrm{~g}$ increase in stem dry weight compared to the control (Table 2).

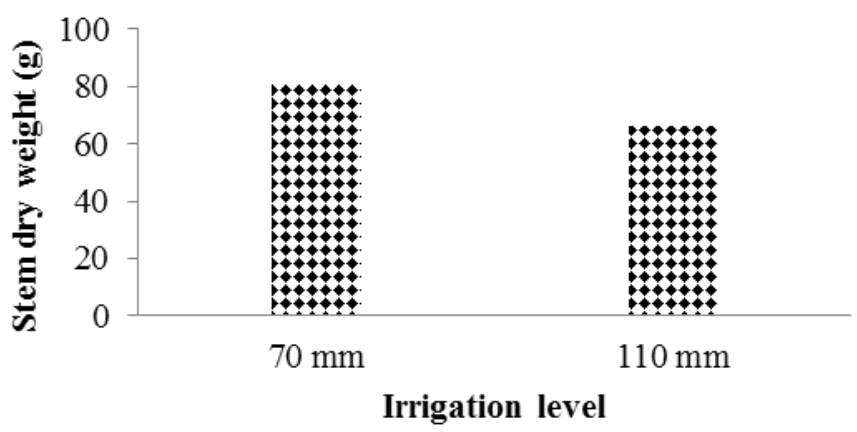

Figure 1. Effect of irrigation levels on stem dry weight. 70 and $110 \mathrm{~mm}$ evaporation from pan are as normal and water deficit conditions, respectively.

\section{Leaf proline concentration}

Seed priming with gamma radiation for $5 \mathrm{~min}$. and magnetic field for $10 \mathrm{~min}$. led to increase in the concentrations of proline by 1.43 and $1.02 \mu \mathrm{mol} \mathrm{g}^{-1}$ of fresh weight compared to the control. Additionally, the laser radiation for $10 \mathrm{~min}$. was more destructive than other treatments, so that the leaf proline concentration decreased by $19 \%$ compared with control and there was no statistically significant difference between other treatments and the control (Table 2).

\section{Biomass}

Interaction of irrigation and physical treatments during two years of experiment demonstrated that the maximum biomass per unit area was obtained from normal irrigation and seed priming with magnetic field in both intervals of 10 and 5 min., and laser and gamma rays of 5 min., respectively while the minimum amount was obtained from water deficit and seeds primed under gamma and laser rays for $10 \mathrm{~min}$. (Figure 2).

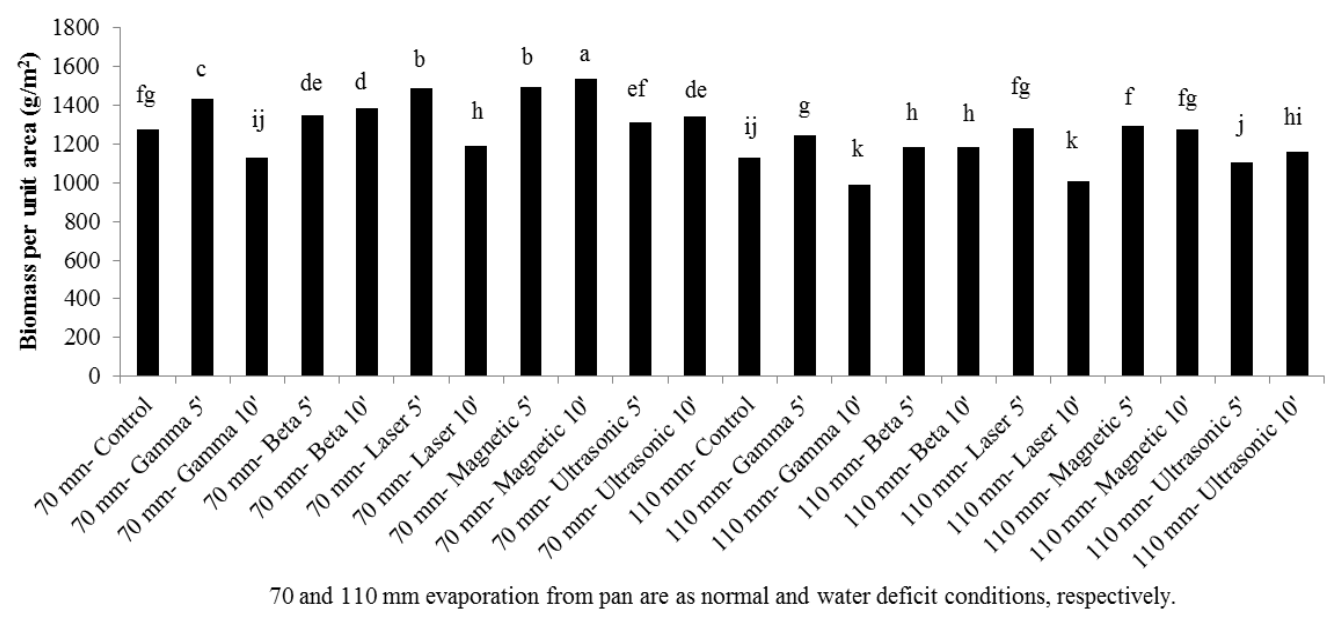

Figure 2. Mean comparisons of physical pre-treatments $\times$ irrigation levels on corn biomass. Means with similar letters in each column are not significant with together by DMRT at 5\% probability level. 
Water deficit led to reduction of biomass compared to normal irrigation in all treatments. In normal irrigation and water deficit conditions primed seeds under magnetic field for 10 and $5 \mathrm{~min}$., laser and gamma rays for $5 \mathrm{~min}$. crop biomass increased as $17 \%$ and $13 \%$ compared to the control, while in those seeds primed with gamma and laser rays for 10 min. biomass reduced $9 \%$ and $12 \%$ compared to the control in both irrigation levels (Figure 2).

Based on means comparison (Figure 2) interaction of irrigation level with priming of gamma and laser rays for $10 \mathrm{~min}$. had major reducing effect on corn biomass.

\section{Grain yield}

The highest grain yield was obtained in normal irrigation and seed priming with magnetic fields for 10 and $5 \mathrm{~min}$. and gamma and laser rays for $5 \mathrm{~min}$. by 808, 790.9, 778.2 , and $758.4 \mathrm{~g} / \mathrm{m}^{2}$ and the lowest value was obtained from water deficit and priming with gamma and laser rays for $10 \mathrm{~min}$. by 458.4 and $473.1 \mathrm{~g} / \mathrm{m}^{2}$, respectively. Also, seed priming with magnetic field for 10 and $5 \mathrm{~min}$. and gamma and laser rays for $5 \mathrm{~min}$. along with the implementation of normal irrigation increased grain yield by 20,18, 16 and $13 \%$, respectively and was considered as the best treatments while priming with gamma ray and laser wave for $10 \mathrm{~min}$. with water deficit showed 32 and $30 \%$ decrease and was considered as the most harmful treatments in grain yield compared with the control. Additionally, water deficit and irrigation implementation based on $110 \mathrm{~mm}$ evaporation reduced yield in all treatments compared with the normal irrigation (Figure 3).

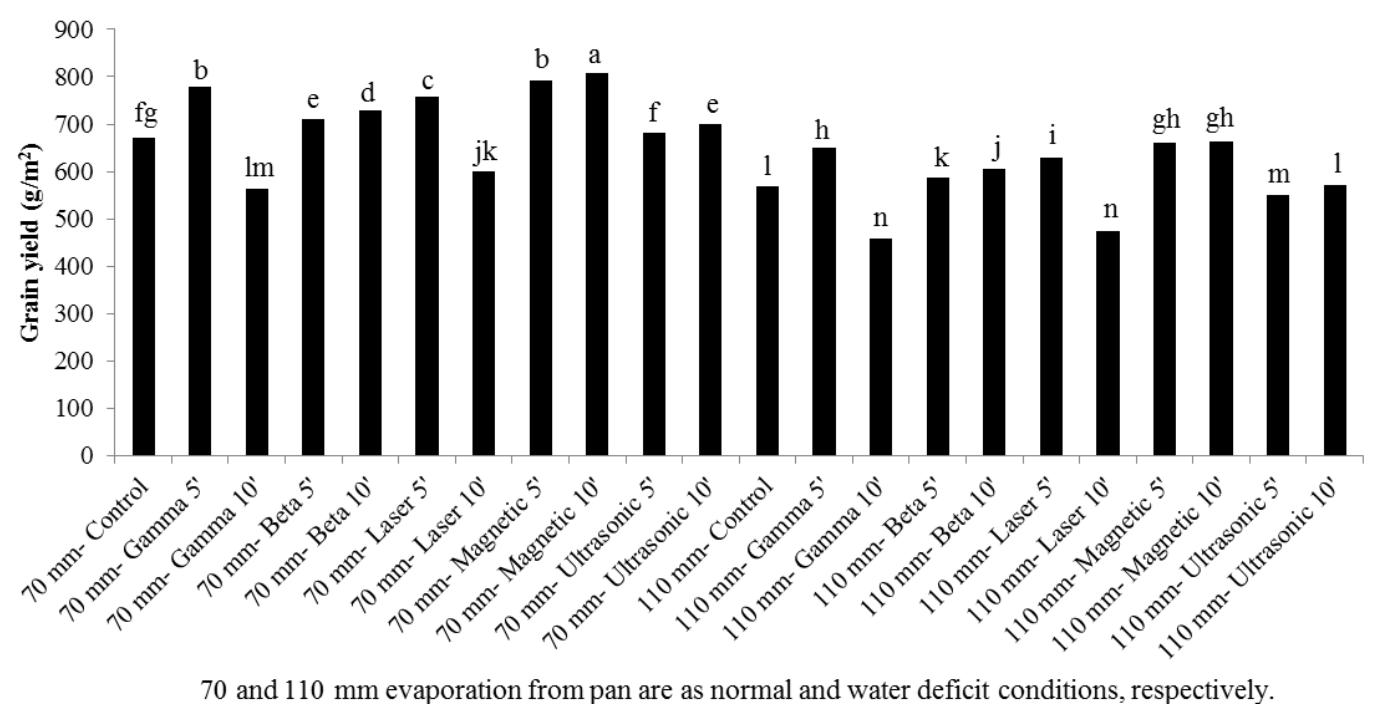

Figure 3. Mean comparisons of physical pre-treatments $\times$ irrigation levels on corn grain yield. Means with similar letters in each column are not significant with together by DMRT at 5\% probability level.

\section{Orthogonal comparison}

Based on the orthogonal comparison results there is a significant difference between 5 and 10 min. physical treatments except to leaf proline concentration. In this study 5 min. interval in all studied traits was better than 10 min. (Table 3). 
Table 3. Orthogonal comparison between 5 and 10 minutes physical pre-treatments, drought and no drought condition of 5 minute magnetic treatment, and finally magnetic and nonmagnetic treatment.

\begin{tabular}{|c|c|c|c|c|c|c|c|c|}
\hline \multicolumn{9}{|c|}{ Traits } \\
\hline & $\begin{array}{l}5 \text { and } 10 \\
\text { minutes }\end{array}$ & $\begin{array}{l}\text { Plant } \\
\text { height } \\
(\mathbf{c m})\end{array}$ & $\begin{array}{c}\text { Time of } \\
\text { tasseling } \\
\text { (day) }\end{array}$ & LAI & $\begin{array}{c}\text { Stem } \\
\text { dry } \\
\text { weight } \\
\text { (g) }\end{array}$ & $\begin{array}{c}\text { Leaf } \\
\text { proline } \\
\text { concen- } \\
\text { tration } \\
(\mu \mathrm{mol} / \mathrm{g})\end{array}$ & $\begin{array}{c}\text { Biomass } \\
\text { per unit } \\
\text { area } \\
\left(\mathrm{g} / \mathrm{m}^{2}\right)\end{array}$ & $\begin{array}{l}\text { Grain } \\
\text { yield } \\
\left(\mathrm{g} / \mathrm{m}^{2}\right)\end{array}$ \\
\hline $\begin{array}{c}\begin{array}{c}\text { Physical } \\
\text { pre- } \\
\text { treatments }\end{array} \\
\end{array}$ & $\begin{array}{l}5 \mathrm{~min} . \\
10 \mathrm{~min} .\end{array}$ & $\begin{array}{l}220.60 \mathrm{a} \\
206.38 \mathrm{~b}\end{array}$ & $\begin{array}{c}67.29 \mathrm{a} \\
72.8 \mathrm{~b}\end{array}$ & $\begin{array}{l}3.72 \mathrm{a} \\
3.19 \mathrm{~b}\end{array}$ & $\begin{array}{l}80.23 \mathrm{a} \\
69.35 \mathrm{~b}\end{array}$ & $\begin{array}{l}4.05 \mathrm{a} \\
3.58 \mathrm{a}\end{array}$ & $\begin{array}{l}1319.2 \mathrm{a} \\
1220.5 \mathrm{~b}\end{array}$ & $\begin{array}{l}679.76 \mathrm{a} \\
617.38 \mathrm{~b}\end{array}$ \\
\hline $\begin{array}{l}\text { a1 } \\
\text { a2 }\end{array}$ & $\begin{array}{l}5 \text { min. } \\
\text { magnetic }\end{array}$ & $\begin{array}{l}225.86 \mathrm{a} \\
215.34 \mathrm{a}\end{array}$ & $\begin{array}{l}69.31 \mathrm{a} \\
65.08 \mathrm{~b}\end{array}$ & $\begin{array}{l}4.09 \mathrm{a} \\
3.34 \mathrm{~b}\end{array}$ & $\begin{array}{l}89.08 \mathrm{a} \\
71.37 \mathrm{~b}\end{array}$ & $\begin{array}{l}3.48 \mathrm{~b} \\
4.62 \mathrm{a}\end{array}$ & $\begin{array}{l}1416.3 \mathrm{a} \\
1222.9 \mathrm{~b}\end{array}$ & $\begin{array}{l}744.3 \mathrm{a} \\
615.3 \mathrm{~b}\end{array}$ \\
\hline All data & $\begin{array}{c}\text { no- } \\
\text { magnetic } \\
\text { magnetic }\end{array}$ & $\begin{array}{l}202.7 \mathrm{~b} \\
237.5 \mathrm{a}\end{array}$ & $\begin{array}{l}69.71 \mathrm{a} \\
62.51 \mathrm{~b}\end{array}$ & $\begin{array}{l}3.16 \mathrm{~b} \\
4.14 \mathrm{a}\end{array}$ & $\begin{array}{l}66.67 \mathrm{~b} \\
91.15 \mathrm{a}\end{array}$ & $\begin{array}{l}3.49 \mathrm{a} \\
4.23 \mathrm{a}\end{array}$ & $\begin{array}{c}1201.9 \mathrm{~b} \\
1401 \mathrm{a}\end{array}$ & $\begin{array}{l}620.54 \mathrm{~b} \\
730.94 \mathrm{a}\end{array}$ \\
\hline
\end{tabular}

a1=normal condition $(70 \mathrm{~mm}$ evaporation from pan)

$\mathrm{a} 2=$ drought stress condition $(110 \mathrm{~mm}$ evaporation from pan $)$

\section{Discussion}

\section{Plant height}

In this research, plant height increased by magnetic field and gamma ray which is in agreement with those reported by Racuciu et al. (2008) on corn and Pasangka (2013) on soybean (Glycine max). Increasing plant height is probably related to stimulating phytohormones like auxin, cytokinin and gibberellin in plant.

\section{Time of tasseling}

In order to premature emergence of radical and plumule of plantlets in field, priming by gamma ray resulted in earlier tasseling. In the Pasangka (2013) experiment flowering stage happened 18 day earlier under gamma ray treatment.

\section{LAI}

The result of this research on corn LAI are in good agreement with findings of Hoseini et al. (2013) on lemon (Melissa officinalis) and Rochalska et al. (2008) on sugar beet (Beta vulgaris). This may a probably result of reported by magnetic field probably since the optimum growth of root in the end of nutrient absorption from soil and finally resulted nutrition transport from stem to leaves as described by Rochalska et al. (2008).

\section{Stem dry weight}

Stem dry weight decline of corn by water deficit like this study, reported by Nesmith and Ritchi (1992) and Singh and Usha (2003). As well increasing of stem dry weight enhanced by seed priming by magnetic field in advance was stated by Florez (2007). 


\section{Biomass}

Reduction in crop biomass under water deficit conditions reported by Rabbani and Imam (2011) and Pirevatlou et al. (2010) on corn and wheat (Triticum aestivum), which is probably resulted from decline in photosynthesis area and assimilate production. Seed priming by magnetic field and laser radiation resulted in higher biomass due to its positive and significant effect on corn LAI. Similar results have reported by Iqbal et al. (2012) in pea (Cicer aritinum) and Hernandez et al. (2010) on corn using magnetic field and laser radiation.

\section{Grain yield}

Based on the results of this study, due to the water deficit from increased irrigation duration from 70 to $110 \mathrm{~mm}$ evaporation, corn grain yield reduced in all treatments, and increasing of duration of seed priming with gamma and laser rays from 5 to $10 \mathrm{~min}$. and accompanying that treatments with water deficit led to significant grain yield loss. Therefore corn seeds priming with magnetic field in both time intervals or under gamma and laser rays only for $5 \mathrm{~min}$. can be used to improvement of grain yield in normal and stress irrigations. Seed priming by magnetic field and laser radiation caused yield improvement via enhancement of growth and LAI followed by increasing of photosynthesis rate. Grain yield increasing reported by Racuciu et al. (2008); Iqbal et al. (2012); Faqenabi et al. (2009) on corn, chickpea and safflower, respectively; using seed priming with magnetic field. According to Pasangka (2013), average grain yield of soybean increased from 2.5 to 4.5 ton/ha via seed priming by gamma ray.

Comparison of physical treatment on groups for $5 \mathrm{~min}$. then $10 \mathrm{~min}$. under both normal and drought conditions demonstrated that for most agronomic traits such as grain yield physical treatments for $5 \mathrm{~min}$. was better than $10 \mathrm{~min}$. and on the other hand comparison of seeds priming with magnetic field with non-treated seeds revealed increases of some important agronomic traits such as grain yield and the biomass.

\section{Conclusions}

As a conclusion from this study, to increase corn grain yield in both normal and water deficit conditions, seed priming with the magnetic field in time intervals of 5 and $10 \mathrm{~min}$., gamma and laser rays only in a short time is recommended. The future studies should be extended to evaluation the response of corn yield when seed exposed under lower intervals of the biophysical treatments.

\section{REFERENCES}

[1] Acquaah, G. (2002): Principles of crop production: (Theory, techniques and technology). - Prentice Hall of India, New Delhi.

[2] Aladjajdjiyan, A. (2014): Ultrasonic stimulation of the development of lentil and wheat seeding. - Romanian Journal of Biophysics 21 (3): 179-187.

[3] Alizadeh, B., Tarinejad, A. (2010): Application of MSTATC software in statistical analysis. - Soutoudeh Publication, Tabriz.

[4] Anonymous. (2015): The biology of Zea mays (L.) (Maize). - Biology document, Canadian Food Inspection Agency 11.

[5] Artola, A., Carrillo-Castaneda, G., Santos, G. D. L. (2003): Hydropriming: A strategy to increase Lotus corniculatus L. seed vigor. - Seed Science and Technology 31: 455-463. 
[6] Bates, L. S., Waldren, R. P., Tevre, I. V. (1973): Rapid determination of free proline for water-stress studies. - Plant Soil 39: 205-207.

[7] Bradford, K. (1995): Water relations in germination. - In: Kiged, J., Galili, G. (eds.) Seed Development and Germination. Marcel Dekker Inc. New York.

[8] Chen, Y. P., Li, L., Wang, F. M. (2002): The effects of He-Ne laser and KT treatment on the seeds germination and growth of wheat. - Acta Laser Biol. Sinica 6: 412-416.

[9] Faqenabi, F., Tajbakhsh, M., Bernooshi, I., Saber-Rezaii, M., Taheri, F., Parvizi, S., Izadkhah, M., Hasanzadeh Gorttapeh, A., Sedqi, H. (2009): The effect of magnetic field on growth, development and yield of safflower and its comparison with other treatments. - Research Journal of Biology Science 4: 174-178.

[10] Farahvash, F., Hoseinpour Feizi, M. A., Madadi Sarai, V., Azarfam, P. (2007): Effect of gamma rays on some physiological traits of wheat. - Journal of Agricultural Science 1(3): 11-22.

[11] Florez, M., Carbonell, M. V., Martinez, E. (2007): Exposure of maize seed to stationary magnetic fields: Effects on germination and early growth. - Environ. Exp. Bot 59: 68-75.

[12] Hamideldin, N., Hussin, O. S. (2014): Morphological, physiological and molecular changes in Solanum tuberosum L. in response to pre-sowing tuber irradiation by gamma rays. - American Journal of Food and Nutrition 2(1): 1-6.

[13] Hernandez, A. C., Carballo, C. A., Artola, A., Michtchenko, A. (2010): Laser irradiation effects on maize seed field performance. - Seed Sci. Technol 34: 193-197.

[14] Hoseini, M., Mirshekari, B., Babazadeh, H. (2013): Influence of biophysical priming on seed germination and yield on two landraces of lemon-balm (Melissa officinalis L.). Not. Sci. Biol 5(2): 238-243.

[15] Iqbal, M., Hag, Z. U., Jamil, Y., Ahmad, M. R. (2012): Effect of pre - sowing magnetic treatment on properties of pea. - International Agrophysics 26: 25-31.

[16] Khan, A., Khalili, S. K., Khan, A. Z., Marwat, K. B., Afzal, A. (2008): The role of seed priming in semi- arid area for mung beam phenology and yield. - Pak. J. Bot 40(6): 24712480.

[17] Marcu, D., Damia, G., Cosma, C., Cristea, V. (2013): Gamma radiation effects on seed germination, growth and pigment content and ESR study of induced free radicals in maize (Zea mays. L.). - Biol Phys DOI: 10.1007/s10887-013-9322-z.

[18] Mokobia, C. E., Anomohanran, O. (2005): The effect of gamma irradiation on the germination and growth of certain Nigerian agricultural crops. - J. Radic.Prot 25(2): 181188.

[19] Moll, R. H., Kamparth, E. J. (1977): Effects of population density up on agronomic traits associated with genetic increases in yield of maize. - Agron. J 69: 81-84.

[20] Nesmith, D. S., Ritchi, J. T. (1992): Short and long-term responses of corn to a preanthesis soil water deficit. - Agronomy Journal 84: 107-113.

[21] Paolo, E. D., Rinaldi, M. (2008): Yield response of corn to irrigation and nitrogen fertilization in a Mediterranean environment. - Field Crops Research 105: 202-210.

[22] Pasangka, B. (2013): The application of multigamma radiation as a physical mutagen for breeding of local soybean. - ARPN Journal of Agricultural and Biological Science 8(5): 450-456.

[23] Pietruszewski, S., Kania, K. (2010): Effect of magnetic field on germination and yield of wheat. - Int Agrophys 24: 297-302.

[24] Pirevatlou, A. S., Dehdar Masjedlou, B., Ramiz, T. A. (2010): Evaluation of yield potential and stress adaptive traits in wheat genotypes under post anthesis drought stress conditions. - African Journal of Agricultural Research 5: 2829-2836.

[25] Rabbani, J., Imam, Y. (2011): Grain yield response of maize hybrids to water stress in different stages of growth. - Journal of Agronomy and Horticultural Products 1(2): 65-78.

[26] Racuciu, M., Creanga, D., Horga, I. (2008): Plant growth under static magnetic field influence. - Romanian Journal of Physics 53: 353-359. 
[27] Rochalska, M., Grabowska, K., Ziarnik, A. (2008): Impact of low frequency magnetic fields on yield and quality of sugar beet. - Int. Agrophysics 23: 163-174.

[28] Singh, B., Usha, K. (2003): Salicylic acid induced physiological and biochemical changes in wheat seedlings under water stress. - Plant Growth Regul 39: 137-141.

[29] Vashisth, A., Nagarajan, S. (2013): Effect of germination and early growth characteristic in sunflower (Helianthus annus) seed exposed to static magnetic field. - Journal of Plant Physiology 167: 149-156.

[30] Yaldagard, M., Mortazavi, S. A. (2008): Application of ultrasonic waves as a priming technique for the germination of barley seed. - Journal of Plant Physiology 114(1): 14-21. 